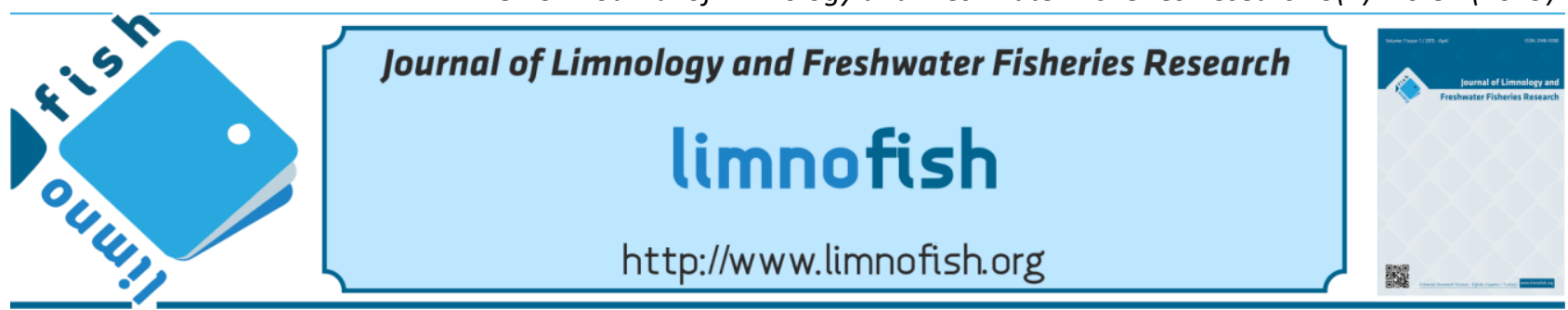

\title{
Heavy Metal Accumulation in Wetland Plants and Water-Sediment Relationship in Köprüören-Kütahya
}

\author{
Betül AKIN (iD) Nüket Akanıl BİNGÖL* \\ Dumlupınar University, Faculty of Arts and Sciences, Department of Biology, 43100 Kütahya, Turkey
}

\section{A B STR ACT}

We investigated the concentrations of boron, zinc, arsenic, silver, lead, copper, cadmium and chromium in water, sediment and boron, zinc and arsenic in some wetland plants (Phragmites australis (Cav.) Trin. Ex Steud, Typha latifolia L., Nasturdium officinale L., Lemna minor L., Lythrum salicaria L., and Ceratophyllum demersum L.) of Kocasu Stream and two related ponds in Köprüören, Kütahya. According to our results, among the eight heavy metals investigated in this study, arsenic was found at high concentration in sediment $(288.66 \mathrm{mg} / \mathrm{kg})$ whereas boron $(903 \mu \mathrm{g} / \mathrm{L})$ was detected in the highest concentration in water samples. We also determined that zinc, boron and arsenic concentrations in plants varied from 70 to $280,37.6$ to 1682.5 , and 0.2 to $34 \mathrm{mg} / \mathrm{kg}$ dry weight (DW), respectively. As a result, it was found that $C$. demersum, $L$. minor and $N$. officinale had the highest accumulation capacity of zinc, boron and arsenic.

Keywords: Bioaccumulation, heavy metal, sediment, water, wetland plants

\section{ARTICLE INFO}

RESEARCH ARTICLE

Received : :18.04.2018

Revised : :21.12.2018

Accepted : :25.01.2019

Published : 27.08.2019

DOI:10.17216/LimnoFish.416601

* CORRESPONDING AUTHOR

nuket.abingol@dpu.edu.tr

Phone : +90 274265 2051/3288

Köprüören-Kütahya'da Yayılış Gösteren Sulak Alan Bitkileri Tarafından Ağır Metal Akümülasyonu ve SuSediment İlişkisi

Öz: Köprüören, Kütahya'da bulunan Kocasu Nehri ile bu nehirle bağlantısı bulunan iki göletin kenarlarında yayılış gösteren bazı sulak alan bitkilerindeki (Phragmites australis (Cav.) Trin. Ex Steud, Typha latifolia L., Nasturdium officinale L., Lemna minor L., Lythrum salicaria ve Ceratophyllum demersum L.) bor, çinko ve arsenic miktarları ile su ve sedimentteki bor, çinko, arsenik, gümüş, kurşun, bakır, kadmiyum ve krom konsantrasyonları tarafımızdan araştırılmıștır. Bu çalışmada araştırılan sekiz ağır metal arasından, arsenik sedimentte yüksek konsantrasyonda bulunurken $(288,66 \mathrm{mg} / \mathrm{kg})$, su numunelerinde en yüksek konsantrasyonda bor $(903 \mu \mathrm{g} / \mathrm{L})$ tespit edilmiştir. Ayrıca, bitkideki çinko, bor ve arsenik konsantrasyonlarının sırasıyla 70-280, 37,6-1682,5 ve 0,2-34 $\mathrm{mg} / \mathrm{kg}$ kuru ağırlık arasında değiştiği saptanmıştır. Sonuç olarak, C. demersum, L. minor ve N. officinale'nin en yüksek çinko, bor ve arsenik biriktirme kapasitesine sahip olduğu bulunmuştur.

Anahtar kelimeler: Biyoakümülasyon, ağır metal, sediment, su, sulak alan bitkileri

How to Cite

Akın B, Bingöl NA. 2019. Heavy Metal Accumulation in Wetland Plants and Water-Sediment Relationship in Köprüören-Kütahya. LimnoFish. 5(2): 76-82. doi: 10.17216/LimnoFish.416601

\section{Introduction}

Heavy metal pollution caused by arsenic (As), boron $(\mathrm{B})$, zinc $(\mathrm{Zn})$, lead $(\mathrm{Pb})$, cadmium $(\mathrm{Cd})$ in fresh waters is one of the most important global environmental issue that we are facing.

Untreated discharges of textiles, metal finishing, mining, ceramic and pharmaceutical industries contaminate freshwaters with heavy metals. Along with the increase in concentrations of heavy metals in freshwater ecosystems, bioaccumulation of these heavy metals by plant and animal species also increasing, and so open a way to toxicity in these living groups (Tchounwou et al. 2012; Priti and Biswajit 2016).

Among heavy metals, $\mathrm{Zn}$ and $\mathrm{B}$ are essential microelements for plant growth and development (Nable et al. 1997; Broadley et al. 2012). However, when $\mathrm{B}$ reaches high levels in the environment (i.e. above $1 \mathrm{mg} \mathrm{B} / \mathrm{L}$ ), it is considered a serious threat to the freshwater resources used for drinking and agriculture purposes (WHO 1998). If boron is deposited at high levels in plant organs, it can cause toxicity symptoms characterized by reduction of shoot-root growth, low chlorophyll content, 
leaf deformations, chlorosis, necrosis, inhibition of pollen germination (Howe 1998; Chen et al. 2014; Farag and Zhang 2014; Tripathi et al. 2015).

$\mathrm{Zn}$, enters the environment through industrial wastes, sewage sludge and acid rains, is one of the most common elements on earth (Paschke et al. 2006). $\mathrm{Zn}$ is an essential trace element that plays important roles in carbohydrate, lipid and nucleic acid metabolisms along with enzyme activation in plants. $\mathrm{Zn}$ is an indispensable micronutrient for plant development, but it can cause toxicity in plants when it reaches high levels in soil and water sources. Although the toxicity threshold of $\mathrm{Zn}$ for plants is uncertain, the visible toxicity symptoms such as curling of young leaves, browning leaf tips and chlorosis appear above $300 \mathrm{mg} \mathrm{Zn/kg} \mathrm{leaf} \mathrm{DW}$ (Broadley et al. 2007; Sharma et al. 2013; Tripathi et al. 2015).

Even though biological function of arsenic is not known well, there are studies showing that As is an essential nutrient for rats, hamsters, minipigs, goats and chickens (Uthus 1992). On the other hand, it limits the uptake of $\mathrm{Fe}$ and $\mathrm{Zn}$, essential for human health, by plants (Li et al. 2016). Arsenic enters the environment through anthropogenic activities such as mining, metal smelting and burning of fossil fuels. It is toxic in high concentrations and causes decrease in fertility, yield and fruit production in plants (Smedley and Kinniburgh 2002; Finnegan and Chen 2012).

Heavy metals are toxic for plants, but some plants are capable of growing in soils and fresh waters with high concentrations of heavy metals and accomplish their detoxification of these metals by various defense mechanisms (Ali et al. 2013). Heavy metal hyperaccumulating plants such as Thlaspi caerulescens L., Polygonum amphibium L., Lemna minor L., Eichhornia crassipes (Mart) Solms., Pistia stratiotes L. are used to remove heavy metals from contaminated ecosystems (Arthur et al. 2005; Lone et al. 2008; Rahman and Hasegawa 2011; Moosavi and Seghatoleslami 2013).

There are important metallic mineral and industrial raw material resources mainly boron, chromium, silver, alunite, antimony, copper-leadzinc, iron, manganese, magnesite, cement raw materials, feldspar, gypsum, fluorite and sand-gravel in Kütahya (Hastorun 2017). In addition, the largest silver deposit of Turkey is located about $7 \mathrm{~km}$ south of the Köprüören, Kütahya. Köprüören region fresh waters, on the banks of the Kocasu stream and two ponds, are used by local people for irrigation purposes. On the other hand, Kocasu stream feeds Felent stream as important water potential for Porsuk River (Anonymous 2017). Unfortunately, silver mining activities cause $\mathrm{As}, \mathrm{Pb}, \mathrm{Sb}$ and $\mathrm{Zn}$ pollution in soil and surface waters in the area (Arslan and
Çelik 2015). On May 7 of 2011, one of the waste storage reservoir pools of the silver factory in Gümüşköy had collapsed. Right after the collapsing, the investigation in the area by authorities reported the necessity of monitoring the region in terms of environmental and health effects (Türkkan ve Soysal 2011). For this reason, our study determined (1) the heavy metal concentrations in sediment and water of two ponds and Kocasu stream in Köprüören where heavy metals inputs were mainly due to mining, municipal wastewaters and farming, and (2) the ability of some wetland plants to accumulate $\mathrm{B}, \mathrm{Zn}$ and As, and (3) investigation of the potential of these plants applicable for phytoremediation studies.

\section{Material and Methods \\ Study site}

Köprüören is located in the western part of Kütahya and $21 \mathrm{~km}$ away from city center. There are two ponds and one stream called Kocasu in the region. One of the ponds, pond 1 , has $63.86 \mathrm{~m}$ length and $40.97 \mathrm{~m}$ width, and the other one, pond 2, has $17.49 \mathrm{~m}$ length and $14.23 \mathrm{~m}$ width (Figure 1, Table 1). The ponds are fed with groundwater and water of the each pond falls into Kocasu stream. Pond 1 is surrounded by fences and used as a recreational area by local people. There are no fences around pond 2 and not used as recreational area. Plant species showing distribution along the pond 1 , pond 2 and Kocasu stream are: Lythrum salicaria L., Phragmites australis (Cav.) Trin. Ex Steud, L. minor L., Typha latifolia L., Nasturdium officinale L., and Ceratophyllum demersum $\mathrm{L}$.

\section{Sample collection}

Samples were collected from pond 1, pond 2 and Kocasu stream in August 2016 in order to determine the $\mathrm{B}, \mathrm{Zn}, \mathrm{As}, \mathrm{Ag}, \mathrm{Pb}, \mathrm{Cu}$ and $\mathrm{Cr}$ concentrations in sediment, water and plant species. Sediment, water and plant samples were collected from nine study points. Sediment samples were collected with scoop with low current velocities in depth of $0-5 \mathrm{~cm}$. After sampling, sediment samples were sealed in clean polypropylene (PP) containers.

In addition, water samples were collected from each study points and placed in PP bottles. Sediment and water samples were kept in a cooler at $4{ }^{\circ} \mathrm{C}$ and transported to the laboratory immediately for further analysis. Plant samples were collected, transported to the laboratory and air-dried at $70^{\circ} \mathrm{C}$ for $48 \mathrm{~h}$.

\section{Analyses of samples}

Heavy metal analyses of all sediments, water and plant samples were performed in Kütahya Dumlupınar University, Advanced Technologies Centre, Kütahya. First, sediment samples were airdried and removed foreign materials by passing the 
dried samples through a $2 \mathrm{~mm}$ sieve and then stored in polypropylene bottles (Đozić et al. 2014). Water samples were filtered to remove suspended materials and stored in PP bottles at $4{ }^{\circ} \mathrm{C}$ in the refrigerator until heavy metal analysis were performed. Dried plant samples were grounded and $0.1 \mathrm{~g}$ plant samples were digested with nitric acid (Merck, Germany) and hydrogen peroxide (Merck, Germany) (Kaçar and
İnal 2008). For heavy metal content determinations, sediment and plant samples were digested and the concentrations of heavy metals ( $\mathrm{Zn}, \mathrm{B}, \mathrm{Pb}, \mathrm{As}, \mathrm{Ag}, \mathrm{Cd}, \mathrm{Cu}$ and $\mathrm{Cr}$ ) in sediment, water, and plant were analyzed by Atomic Absorption Spectrometer (AAS, Analytikjena ContrAA 300) (Kütahya Dumlupınar Üniversitesi 2018).

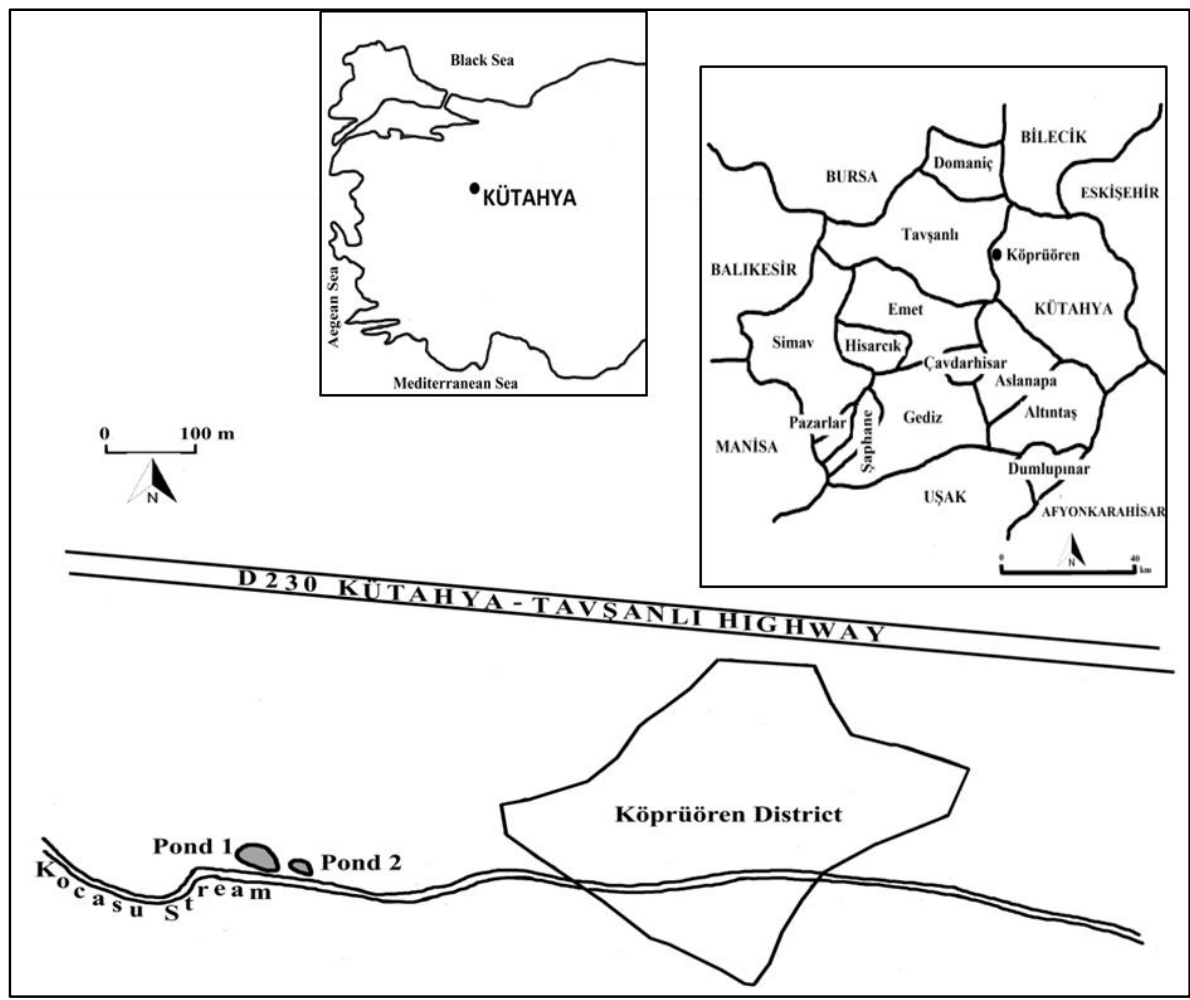

Figure 1. Location of pond 1, pond 2 and Kocasu Stream in Köprüören District.

Table 1. Locations of sampling points.

\begin{tabular}{|c|c|c|c|c|}
\hline Study Sites & $\begin{array}{l}\text { Sampling } \\
\text { Points } \\
\end{array}$ & Sample Type & $\begin{array}{l}\text { Coordinates } \\
\text { Latitude } \\
\end{array}$ & Longitude \\
\hline \multirow{3}{*}{ Pond 1} & 1 & $\begin{array}{l}\text { Water } \\
\text { Sediment } \\
\text { Plant }\end{array}$ & $39^{\circ} 30^{\prime} 27^{\prime \prime}$ & $29^{\circ} 44^{\prime} 59^{\prime \prime}$ \\
\hline & 2 & $\begin{array}{l}\text { Water } \\
\text { Sediment } \\
\text { Plant }\end{array}$ & $39^{\circ} 30^{\prime} 27^{\prime \prime}$ & $29^{\circ} 44^{\prime} 55^{\prime \prime}$ \\
\hline & 3 & $\begin{array}{l}\text { Water } \\
\text { Sediment } \\
\text { Plant }\end{array}$ & $39^{\circ} 30^{\prime} 26^{\prime \prime}$ & $29^{\circ} 44^{\prime} 59^{\prime \prime}$ \\
\hline \multirow{3}{*}{ Pond 2} & 1 & $\begin{array}{l}\text { Water } \\
\text { Sediment } \\
\text { Plant }\end{array}$ & $39^{\circ} 30^{\prime} 25^{\prime \prime}$ & $29^{\circ} 45^{\prime} 00^{\prime \prime}$ \\
\hline & 2 & $\begin{array}{l}\text { Water } \\
\text { Sediment } \\
\text { Plant }\end{array}$ & $39^{\circ} 30^{\prime} 26^{\prime \prime}$ & $29^{\circ} 45^{\prime} 01^{\prime \prime}$ \\
\hline & 3 & $\begin{array}{l}\text { Water } \\
\text { Sediment } \\
\text { Plant }\end{array}$ & $39^{\circ} 30^{\prime} 25^{\prime \prime}$ & $29^{\circ} 45^{\prime} 02^{\prime \prime}$ \\
\hline \multirow{3}{*}{ Stream } & 1 & $\begin{array}{l}\text { Water } \\
\text { Sediment } \\
\text { Plant }\end{array}$ & $39^{\circ} 30^{\prime} 25^{\prime \prime}$ & $29^{\circ} 45^{\prime} 00^{\prime \prime}$ \\
\hline & 2 & $\begin{array}{l}\text { Water } \\
\text { Sediment } \\
\text { Plant }\end{array}$ & $39^{\circ} 30^{\prime} 26^{\prime \prime}$ & $29^{\circ} 45^{\prime} 01^{\prime \prime}$ \\
\hline & 3 & $\begin{array}{l}\text { Water } \\
\text { Sediment } \\
\text { Plant }\end{array}$ & $39^{\circ} 30^{\prime} 25^{\prime \prime}$ & $29^{\circ} 45^{\prime} 02^{\prime \prime}$ \\
\hline
\end{tabular}




\section{Statistical analysis}

All values were expressed as the mean \pm standard deviation of triplicates. Results were evaluated by JMP 6 SAS (JMP SAS 1995) statistical program. Ftest was used to determine the differences between the heavy metal accumulation in plants at $p<0.05$ level. TUKEY-HSD multiple comparison test was used on these applications that statistically different according to F-test.

\section{Results}

The results of heavy metal analysis in sediment and water samples were presented in Table 2.
According to AAS results, $\mathrm{Ag}, \mathrm{Cd}, \mathrm{Cu}$ and $\mathrm{Cr}$ were detected below detection limit in sediment samples. $\mathrm{Zn}, \mathrm{B}, \mathrm{As}$ and $\mathrm{Pb}$ concentrations varied from 133.98 to $215.88,132.57$ to $170.71,86.49$ to 233.44 and 17.19 to $288.66 \mathrm{mg} / \mathrm{kg}$ in sediment, respectively. When the distribution of heavy metal concentration were considered, while $\mathrm{Pb}, \mathrm{As}, \mathrm{Ag}, \mathrm{Cd}$, $\mathrm{Cu}$ and $\mathrm{Cr}$ were under detection limit, $\mathrm{Zn}$ and $\mathrm{B}$ concentrations varied from 31 to $65 \mu \mathrm{g} / \mathrm{L}$ and from 800 to $903 \mu \mathrm{g} / \mathrm{L}$ in water, respectively. According to the results of our study, it was determined that heavy metals in sediment were higher than water (Table 2).

Table 2. Mean heavy metal concentrations of sediment and water samples in pond 1, pond 2 and Kocasu Stream, Kütahya.

\begin{tabular}{cccccc}
\hline & & $\mathbf{Z n}^{*}$ & $\mathbf{B}^{*}$ & $\mathbf{P b}^{*}$ & $\mathbf{A s}^{* *}$ \\
\hline \multirow{2}{*}{ Heavy metals in } & Pond 1 & $150.76 \pm 69.97^{* * *}$ & $170.71 \pm 27.09$ & $86.49 \pm 63.00$ & $29.72 \pm 17.50$ \\
sediment (mg/kg) & Pond 2 & $133.98 \pm 14.01$ & $132.57 \pm 30.31$ & $170.83 \pm 86.43$ & $17.19 \pm 6.54$ \\
& Stream & $215.88 \pm 90.02$ & $141.66 \pm 66.59$ & $233.44 \pm 107.81$ & $288.66 \pm 162.50$ \\
\hline \multirow{2}{*}{ Heavy metals in } & Pond 1 & $65 \pm 98.11$ & $800 \pm 92.31$ & $\mathrm{BDL}^{1}$ & $\mathrm{BDL}^{2}$ \\
water $(\boldsymbol{\mu g} / \mathbf{L})$ & Pond 2 & $31 \pm 7.5$ & $811 \pm 105.06$ & $\mathrm{BDL}^{1}$ & BDL $^{2}$ \\
& Stream & $36 \pm 20.28$ & $903 \pm 266.47$ & BDL $^{1}$ & BDL $^{2}$ \\
\hline
\end{tabular}

* Flame Atomic Absorption Spectrometry, ** Hydride Generation Atomic Absorption Spectrometry

${ }^{1}$ Below Detection Limit $(<0.1 \mathrm{mg} / \mathrm{L}),{ }^{2}$ Below Detection Limit $(<5 \mu \mathrm{g} / \mathrm{ml})$.

*** Standard error, $\mathrm{n}=3$
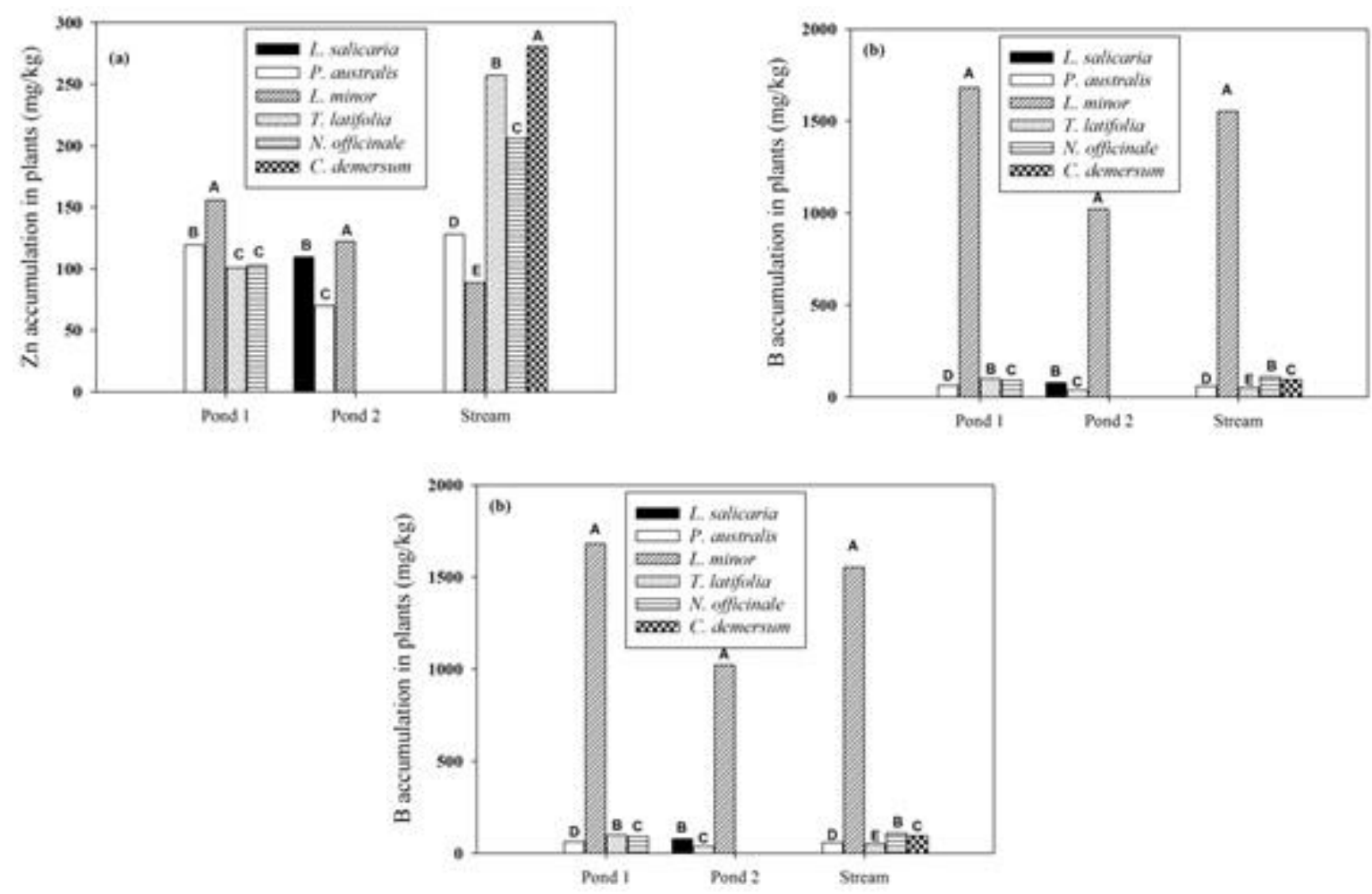

Figure 2. Zinc (a), boron (b) and arsenic (c) accumulation (mg/kg) in L. salicaria, P. australis, L. minor, T. latifolia, N. officinalis, and $C$. demersum that show distribution along the pond 1, pond 2 and Kocasu stream, Kütahya.

Heavy metal accumulations in plants were presented in Figure 2. While maximum $\mathrm{Zn}$ accumulation was obtained in C. demersum (280 \pm $0.67 \mathrm{mg} / \mathrm{kg}$ ), minimum $\mathrm{Zn}$ accumulation was determined in $P$. australis $(70.1 \pm 0.58 \mathrm{mg} / \mathrm{kg})$. When
$\mathrm{Zn}$ accumulation ability of plants in pond 1 was compared to each other, there were statistically significant differences between mean $\mathrm{Zn}$ accumulations of plants. L. minor plant $(155.8 \pm 0.26$ $\mathrm{mg} / \mathrm{kg}$ ) zinc accumulation potential is statistically 
important than $P$. australis $(119.3 \pm 0.79 \mathrm{mg} / \mathrm{kg})$, T. latifolia $(100.6 \pm 0.67 \mathrm{mg} / \mathrm{kg})$ and $N$. officinale $(103 \pm 0.10 \mathrm{mg} / \mathrm{kg})$ in pond 1 . In addition, $C$. demersum $(280 \pm 0.57 \mathrm{mg} / \mathrm{kg})$ in stream and L. minor $(122.3 \pm 0.75 \mathrm{mg} / \mathrm{kg})$ in pond 2 had more accumulation capacity of $\mathrm{Zn}$ than others.

Boron concentrations of the plants in pond 1, pond 2 and stream varied from $37.6 \pm 0.31$ to 1682.5 $\pm 0.84 \mathrm{mg} / \mathrm{kg}$. The results of statistical analyses showed that the maximum boron accumulation was found in L. minor and minimum boron accumulation was found in P. australis in all points (Figure 2).

Arsenic concentrations of the plants in pond 1, pond 2 and Kocasu stream varied from $0.2 \pm 0.06$ to $34 \pm 0.53 \mathrm{mg} / \mathrm{kg}$. The maximum arsenic accumulation was found in $N$. officinale $(34 \pm 0.53$ $\mathrm{mg} / \mathrm{kg})$ and C. demersum $(16 \pm 0.76 \mathrm{mg} / \mathrm{kg})$ grown in stream. Thus, the arsenic accumulation by $N$. officinale was considerably higher than other aquatic plants. The minimum As accumulation was found in P. australis (Figure 2).

\section{Discussion}

Among the eight heavy metals investigated in Kocasu stream and two related ponds in Köprüören, arsenic and boron were found at high concentrations in sediment and water samples, respectively. Arslan and Çelik 2015 found that pollution index values were high in stream sediments collected from Köprüören Basin. On the other hand, Çiçek et al. 2013 and Tokatli et al. 2012 also found that Köprüören village and Felent River were ecologically at risk in term of arsenic heavy metal.

In this study, it was found that the concentrations of $\mathrm{Pb}$ and $\mathrm{Cr}$ in the water samples collected from Kocasu Stream and related two ponds were below detection limit. However, Yuce et al. 2005 and Kose et al. 2015 have found that concentration of $\mathrm{Pb}$ and $\mathrm{Cr}$ metals in Porsuk River were over the maximum contamination level. It was thought that the reason for the increase in concentration of these metals is associated with the wastewater contamination from porcelain factories along Porsuk River.

The highest zinc accumulation was observed in C. demersum and T. latifolia in Kocasu stream. Ghobrial (2000) showed that $C$. demersum could accumulate high concentration of $\mathrm{Zn}$ inside its tissues and acts as biological filter for detoxification of domestic effluents. According to research of Kumari and Tripathi (2015), T. latifolia plant has the best removal capacity of $\mathrm{Zn}$ among $\mathrm{Cu}, \mathrm{Fe}, \mathrm{Ni}$, $\mathrm{Cr}, \mathrm{Pb}$ and $\mathrm{Cd}$ heavy metals $(52.4 \%)$. Klink et al. (2013) have stated more zinc was accumulated in root of $T$. latifolia than its stem, so they have identified it as root accumulator plant.
It has been found that $L$. minor accumulate higher concentrations of B than $N$. officinale, T. latifolia, C. demersum, L. salicaria, P. australis. Lemna spp., floating aquatic plant, accumulates high concentration of B with its whole plant surface (Del-Campo Marin and Oron 2007; Böcük et al. 2013). Gür et al. (2016) found that L. minor accumulated $4007 \mathrm{mg} \mathrm{B} / \mathrm{kg}$ after a 7-day treatment period. Tatar and Öbek (2014) also determined that B uptake by L. minor changes between $140 \mathrm{mg} \mathrm{B/g}$ and $274 \mathrm{mg} \mathrm{B} / \mathrm{g}$.

$N$. officinale and C. demersum plants were found to accumulate maximum Arsenic in their tissues. $N$. officinale can accumulate high concentration of Arsenic in roots, shoots and leaves under favorable growth conditions (Rahman and Hasegawa 2011; Kisten et al. 2015). According to Ozturk et al. (2010) watercress ( $N$. officinale) can accumulate large amounts of Arsenic in its leaves when the plant exposed to $50 \mathrm{M}$ of As. On the other hand, Gounden et al. (2016) determined that watercress plants exposed to over $5 \mathrm{ppm}$ As died after one week of treatment. There are reports about As accumulation presented by a number of authors including Mishra et al. (2013), Srivastava et al. (2014) and Xue et al. (2012), and they all have indicated that $C$. demersum was a potential As accumulator submerged macrophyte plant (76 $\mu \mathrm{g}$ As/g d.w, $489 \mu \mathrm{g}$ As/g d.w. and $963 \mu \mathrm{g}$ As/g d.w., respectively).

In recent years, heavy metal pollution due to industrial and agricultural activities has threatened water ecosystems. Especially metal mines and mine processing activities in Kütahya have caused heavy metal pollution in fresh waters. Aquatic plants and macrophytes are one of the main biological component of the fresh water, and able to accumulate high concentrations of heavy metals in their tissues (Matache 2013). In the present study, heavy metal accumulation in some wetlands plants and its relation with sediment and water in KöprüörenKütahya were investigated. The data showed that while $\mathrm{Zn}, \mathrm{B}, \mathrm{Pb}$ and $\mathrm{As}$ was found in the sediments, only $\mathrm{Zn}$ and $\mathrm{B}$ heavy metals were detected in water samples and $\mathrm{B}, \mathrm{Zn}$ and As were found in plants. In this study, it was cleared that C. demersum, L. minor and N. officinale have high capacity to accumulate heavy metal in their tissues, and these aquatic plants can be used for phytoremediation.

\section{References}

Ali H, Khan E, Sajad MA. 2013. Phytoremediation of heavy metals-concepts and applications. Chemosphere. 91(7):869-881. doi: 10.1016/j.chemosphere.2013.01.075 
Anonymous 2017. The environmental situation report of Kütahya city. Kütahya: Kütahya Governorship Environment and Urbanisation Province Directorate 153 p. [in Turkish]

Arslan Ş, Çelik M. 2015. Assessment of the pollutants in soils and surface waters around Gümüş Köy Silver Mine (Kütahya, Turkey). B Environ Contam Tox. 95(4):499-506. doi: 10.1007/s00128-015-1613-6

Arthur EL, Rice PJ, Rice PJ, Anderson TA, Baladi SM, Henderson KLD, Coats JR. 2005. Phytoremediation an overview. Crit Rev Plant Sci. 24(2):109-122. doi: 10.1080/07352680590952496

Böcük H, Yakar A, Türker OC. 2013. Assessment of Lemna gibba L. (duckweed) as a potential ecological indicator for contaminated aquatic ecosystem by boron mine effluent. Ecol Indic. 29:538-548. doi: 10.1016/j.ecolind.2013.01.029

Broadley MR, White PJ, Hammond JP, Zelko I, Lux A. 2007. Zinc in plants. New Phytol. 173:677-702. doi: 10.1111/j.1469-8137.2007.01996.x

Broadley MR, Brown P, Cakmak I, Rengel Z, Zhao F. 2012. Function of nutrients: Micronutrients. In: Marschner P. editor. Mineral Nutrition of Higher Plants. USA: Academic Press. p. 191-243.

Chen M, Mishraa S, Heckathorna SA, Frantzb JM, Krauseb C. 2014. Proteomic analysis of Arabidopsis thaliana leaves in response to acute boron deficiency and toxicity reveals effects on photosynthesis, carbohydrate metabolism, and protein synthesis. J Plant Physiol. 171(3-4):235-242. doi: 10.1016/j.jplph.2013.07.008

Çiçek A, Tokatli C, Köse E. 2013. Ecological risk assessment of heavy metals in sediment of Felent Stream, Sakarya River Basin, Turkey. Pakistan J Zool. 45(5):1335-1341.

Del-Campo Marin CM, Oron G. 2007. Boron removal by the duckweed Lemna gibba: A potential method for the remediation of boron-polluted waters. Water Res. 41(20):4579-4584. doi: 10.1016/j.watres.2007.06.051

Đozić A, Selimbašić V, Cipurković A, Tanjić I, Uljić M, Zohorović M. 2014. Metal pollution assessment in sediments of the Spreča River. Technologica Acta. 7(1):69-79.

Farag M, Zhang MF. 2014. Effect of boron toxicity stress on seed germination, root elongation and early seedling development of watermelon Citrullus lanatus Thumb. J Anim Plant Sci. 21(2):3313-3325.

Finnegan PM, Chen W. 2012. Arsenic Toxicity: The effects on plant metabolism. Front Physiol. 3:1-18. doi: 10.3389/fphys.2012.00182

Ghobrial MG. 2000. Treatment of cadmium, copper, zinc and iron in wastewater by the hornwort Ceratophyllum demersum. Egyptian Journal of Aquatic Biology and Fisheries. 4(1):35-46. doi: 10.21608/ejabf.2000.1639

Gounden D, Kisten K, Moodley R, Shaik S, Jonnalagadda SB. 2016. Impact of spiked concentrations of $\mathrm{Cd}, \mathrm{Pb}$, As and $\mathrm{Zn}$ in growth medium on elemental uptake of
Nasturtium officinale (watercress). J Environ Sci Heal B. 51(1):1-7. doi: 10.1080/03601234.2015.1080477

Gür N, Türker OC, Böcük, H. 2016. Toxicity assessment of boron (B) by Lemna minor L. and Lemna gibba L. and their possible use as model plants for ecological risk assessment of aquatic ecosystems with boron pollution. Chemosphere. 157:1-9. doi: 10.1016/j.chemosphere.2016.04.138

Hastorun S. 2017. The Mineral Industry of Turkey. 2014 U.S. Geological Survey Minerals Yearbook, Turkey. 46.1-46.26.

Howe PD. 1998. A review of boron effects in the environment. Biol Trace Elem Res. 66(1-3):153-166. doi: 10.1007/BF02783135

JMP SAS 1995. JMP. Cary, NC, USA: SAS Institute Inc 302 p. p.

Kaçar B, İnal A. 2008. Bitki Analizleri. Ankara: Nobel Yayın Dağıtım Ltd. Şti 892 p. [in Turkish].

Kisten K, Gounden D, Moodley R, Jonnalagadda SB. 2015. Elemental distribution and uptake by watercress (Nasturtium aquaticum) as a function of water quality. J Environ Sci Heal B. 50(6):439-447. doi: 10.1080/03601234.2015.1011971

Klink A, Macioł A, Wisłocka M, Krawczyk J. 2013. Metal accumulation and distribution in the organs of Typha latifolia L. (Cattail) and their potential use in bioindication. Limnologica. 43(3):164-168. doi: 10.1016/j.limno.2012.08.012

Kose E, Cicek A, Uysal K, Tokatlı C, Emiroglu O, Arslan N. 2015. Heavy Metal accumulations in water, sediment, and some cyprinid species in Porsuk Stream (Turkey). Water Environ Res. 87(3):195-204. doi: 10.2175/106143015X14212658612993

Kumari M, Tripathi BD. 2015. Efficiency of Phragmites australis and Typha latifolia for heavy metal removal from wastewater. Ecotoxicol Environ Saf. 112:80-86. doi: 10.1016/j.ecoenv.2014.10.034

Kütahya Dumlupınar Üniversitesi 2018. İleri Teknolojiler Merkezi; [cited 2018 Aug 24]. Available from https://iltem.dpu.edu.tr/analiz-ucretleri/.

Li N, Wang J, Song W-Y. 2016. Arsenic uptake and translocation in plants. Plant and Cell Physiology. 57(1):4-13. doi: $10.1093 / \mathrm{pcp} / \mathrm{pcv} 143$

Lone MI, He Z, Stoffella PJ, Yang X. 2008. Phytoremediation of heavy metal polluted soils and water: Progresses and perspectives. J Zhejiang Univ Sci B. 9(3):210-220. doi: 10.1631/jzus.B0710633

Matache ML, Marin C, Tudorache A, Rozylowicz L. 2013. Plants accumulating heavy metals in the Danube River wetlands. J Environ Health Sci. 11(39):1-7. doi: 10.1186/2052-336X-11-39

Mishra S, Wellenreuther G, Mattusch J, Stark HJ, Kupper H. 2013. Speciation and distribution of arsenic in the non-hyperaccumulator macrophyte Ceratophyllum demersum. Plant Physiol. 163:1396-1408. doi: 10.1104/pp.113.224303

Moosavi SG, Seghatoleslami MJ. 2013. Phytoremediation: A review. Adv Agri Biol. 1(1):5-11. 
Nable RO, Bañuelos GS, Paull JG. 1997. Boron toxicity. Plant Soil. 193(2):181-198. doi: 10.1023/A:1004272227886

Ozturk F, Duman F, Leblebici Z, Temizgul R. 2010. Arsenic accumulation and biological responses of watercress (Nasturtium officinale R. Br.) exposed to arsenite. Environ Exp Bot. 69(2):167-174. doi: 10.1016/j.envexpbot.2010.03.006

Paschke MW, Perry LG, Redente EF. 2006. Zinc toxicity thresholds for reclamation forb species. Water Air Soil Poll. 170(1-4):317-330. doi: 10.1007/s11270-006-3139-3

Priti S, Biswajit B. 2016. Assessment of heavy metal pollution in water resources and their impacts: A Review. Journal of Basic and Applied Engineering Research. 3(8):671-675.

Rahman MA, Hasegawa H. 2011. Aquatic arsenic: Phytoremediation using floating macrophytes. Chemosphere. 83(5):633-646. doi: 10.1016/j.chemosphere.2011.02.045

Sharma A, Patni B, Shankhdhar D, Shankhdhar SC. 2013. Zinc - An Indispensable Micronutrient. Physiol Mol Biol Pla. 19(1):11-20. doi: 10.1007/s12298-012-0139-1

Smedley PL, Kinniburgh DG. 2002. A Review of the source, behaviour and distribution of arsenic in natural waters. Appl Geochem. 17(5):517-568. doi: 10.1016/S0883-2927(02)00018-5

Srivastava S, Sounderajan S, Udas A, Suprasanna P. 2014. Effect of combinations of aquatic plants (Hydrilla, Ceratophyllum, Eichhornia, Lemna and Wolffia) on arsenic removal in field conditions. Ecol Eng. 73:297-301. doi: 10.1016/j.ecoleng.2014.09.029

Tatar ŞY, Öbek E. 2014. Potential of Lemna gibba L. and Lemna minor $\mathrm{L}$. for accumulation of boron from secondary effluents. Ecol Eng. 70:332-336.

doi: 10.1016/j.ecoleng.2014.06.033
Tchounwou PB, Yedjou CG, Patlolla AK, Sutton DJ. 2012. Heavy metal toxicity and the environment. In: Luch, A. editor. Molecular, Clinical and Environmental Toxicology. Basel: Springer. p. 133-164.

Tokatlı C, Köse E, Çiçek A, Arslan N, Emiroğlu Ö. 2012. Evaluations of water quality and the determination of trace elements on biotic and abiotic components of Felent Stream (Kütahya, Sakarya River Basin/Turkey). Biological Diversity and Conservation. 5/2:73-80.

Tripathi DK, Singh S, Singh S, Mishra S, Chauhan DK, Dubey NK. 2015. Micronutrients and their diverse role in agricultural crops: advances and future prospective. Acta Physiol Plant. 37(139):1-14. doi: 10.1007/s11738-015-1870-3

Türkkan A, Soysal A. 2011. TTB Kütahya Gümüşköy gümüş madeni atik depolama baraj göçüğü inceleme raporu; [ cited 2018 Aug 15]. Available from https://ttb.org.tr/images/stories/file/TTBKUTAHYA RAPOR.doc

Uthus E. O. 1992. Evidence for arsenic essentiality. Environ Geochem Hlth. 14(2): 55-58. doi: 10.1007/BF01783629

World Health Organization 1998. Environmental Health Criteria 204; [cited 2018 Aug 24]. Available from http://www.inchem.org/documents/ehc/ehc/ehc 204.htm

Xue P, Yan C, Sun G, Luo Z. 2012. Arsenic accumulation and speciation in the submerged macrophyte Ceratophyllum demersum L. Environ Sci Pollut R. 19(9):3969-3976. doi: 10.1007/s11356-012-0856-6

Yuce G, Pinarbasi A, Ozcelik S, Ugurluoglu D. 2005. Soil and water pollution derived from anthropogenic activities in the Porsuk River Basin, Turkey. Environ Geol. 49:359-375 doi: 10.1007/s00254-005-0072-5 